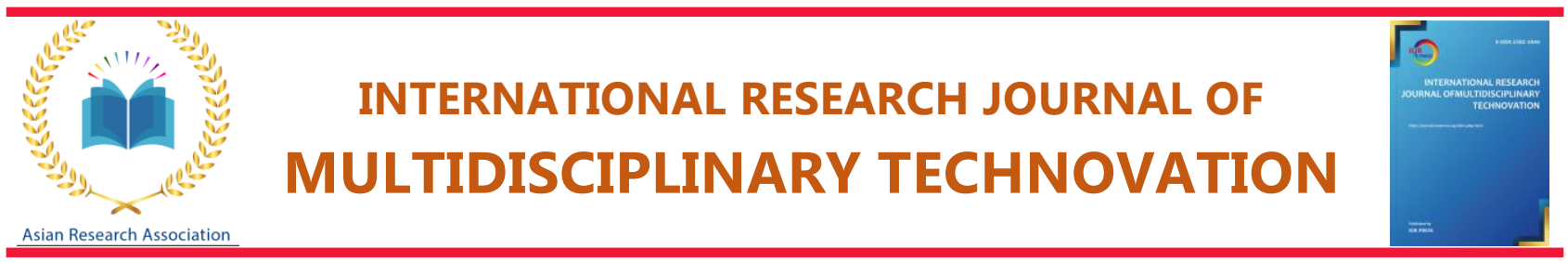

\title{
Analysis of Modern Aviation Fuels: A Review of Environment Effect
}

\author{
A. Sinem Gürkan Aydin ${ }^{1,}$ *, B. Oktay Polat ${ }^{2}$, A. Arzu Ozgen ${ }^{1}$ \\ ${ }^{1}$ University Department of Vocational School of Health Services, Istanbul Gelisim University, İstanbul, Turkey \\ 2 Department of School of Applied Sciences, Istanbul Gelisim University, İstanbul, Turkey \\ ${ }^{*}$ Corresponding authors email: sgurkan@gelisim.edu.tr \\ DOI: https://doi.org/10.34256/irjmt21411 \\ Received: 13-05-2021, Accepted: 25-07-2021, Accepted: 28-07-2021, Published: 30-07-2021
}

Abstract: In our developing and changing world, the use of energy resources is becoming important. With the development of the aviation industry all over the world, the need to use more innovative, more sustainable resources emerges. When the demands in the transportation sector from past to present are examined, the transformation in energy resources will be inevitable. As stated, all studies have focused on the energy resources that reduce the environmental impact, sustainability, environmental friendliness, costs and dependence on oil producing states. In this study, the study of aviation fuels from past to present, its production, environmental impact, sustainability and the returns of alternative aviation fuels are discussed in detail. It is concluded that the world's developing and changing aviation sector should switch to sustainable alternative fuels as soon as possible.

Keywords: Energy, Sustainability, Aviation fuels, Pollution

\section{Introduction}

Energy is very important to the development of all countries and in our survival [1]. It is also the most important factor in the development of countries and the increase in living standards. Along with the increase in the world population, the changes and developments in the sector increase the energy need gradually [1-2]

The use of energy resources worldwide has increased by $2.5 \%$ compared to the previous year and the increase has become more visible since 2012. The superiority of fossil fuels in energy consumption continues [2-3]. According to the studies conducted in 2016; petroleum has the highest rate with $33.3 \%$ of energy consumption. In the world, $28.1 \%$ of energy consumption is coal, $24.1 \%$ is natural gas, $6.9 \%$ is hydraulic energy, $4.5 \%$ is nuclear energy and finally $3.2 \%$ is sustainable energy sources [4]. Primary energy consumption rates based on global resources are as shown in Figure 1.

Global sectoral distribution of primary energy consumption is as shown in Figure 2. The sector that consumes the most in the total energy scale is transportation, which constitutes one in three. Following this share, the industry sector ranks second with a rate of $31 \%$ [5]

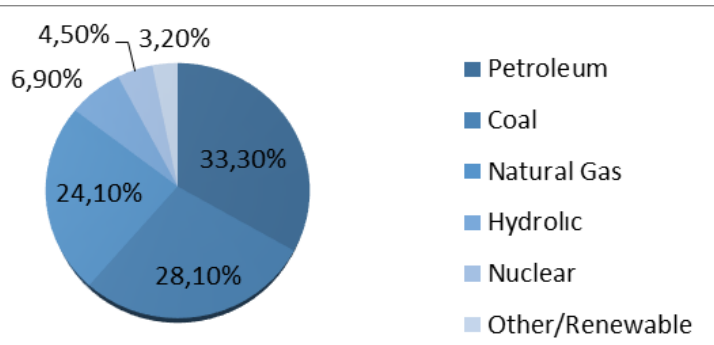

Figure 1. Primary energy consumption rates based on global resources

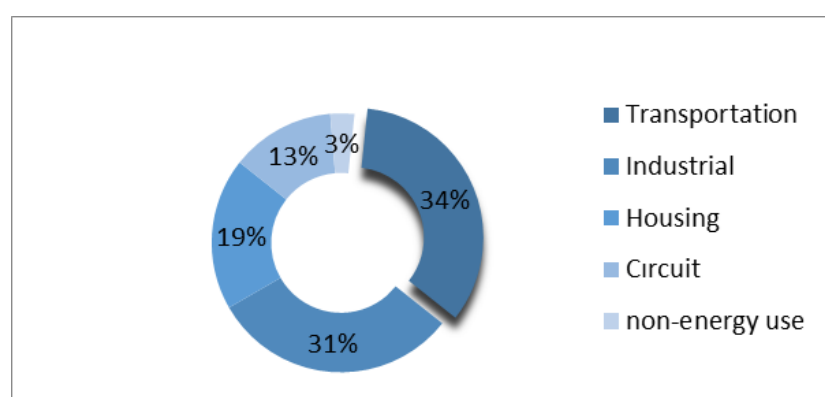

Figure 2. Sectoral distribution of primary energy consumption

The transportation sector generally prefers to use petroleum-based fuels. In $2011,54 \%$ of the world's oil consumption was in the transportation sector, which consists of road, aviation, maritime and railway transportation, $18 \%$ in the industrial sector, $11 \%$ in the domestic, commercial and agricultural areas, $10 \%$ in 
the petrochemical industry, $7 \%$ has been in electricity production [4] According to the projections of oil consumption change on a sectoral basis until 2020, $74 \%$ of the increase in oil consumption is estimated to be in the transportation sector. For this reason, the change in the world vehicle park and the number of vehicles per capita is of great importance in the future oil consumption projections, and these rates are closely followed by the oil producing countries [6-8].

Although primary energy consumption has shown the fastest increase since 2010, it has exceeded the rate of $10 \%$ per year compared to last year. More than $40 \%$ of the increase in fuel consumption and energy consumption resulted from the use of natural gas. Use in all fuel types except renewable energy has increased faster than 10-year averages. However, its biggest secondary increase still constitutes renewable energy sources. China, the USA and India account for more than two thirds of the global increase in energy demand in the world. In addition, consumption in the USA has reached the highest level in the last 30 years [9].

The reason for this increase is developing depending on the needs of the society and countries. Modern society is dependent on transportation according to need. Although the transportation in the world is increasing day by day, there were approximately 1.2 billion light commercial vehicles (LDV) and around 380 million trucks in 2015 [1]. It is foreseen that these numbers will reach 107-109 billion in countries such as India, China, which are not OECD members by 2040 Approximately $20 \%$ of all energy used is transportation. $23 \%$ of global carbon dioxide (CO2) formation is again transportation. Transportation contributes to only $14 \%$ of global greenhouse gas (GHG) emissions. At present, gases such as methane must be included for internal combustion engines to transmit power almost entirely with piston engines powering land and sea transport and jet engines powering air transport. This causes spark ignition (SI) engines to power approximately $80 \%$ of all vehicles worldwide [10].

$95 \%$ of the energy required for transportation is produced from petroleum fuel. Intercalarily, approximately $60 \%$ of the crude oil produced is used to make transportation fuels [11-14]. Demand for transportation fuels worldwide is huge, 4.9 billion liters of gasoline and diesel each, and 1.3 billion liters of jet fuel each [8], with an expected growth of about year $1 \%$ [11]. Natural gas and biofuels may be preferred to traditional fuels produced from crude oil. But, all of these alternatives to the existing system start from a very small base and face critical obstacles for rapid and unlimited growth., Even by 2040 - not expected to account for more than $10 \%$ of global transport energy $[12,15]$. It is important to evaluate alternatives and not to shift the load on the exhaust pipe to ensure environmental benefits.

However, civil aviation has an important place in the transportation industry today While Civil Aviation was a sector that was responsible for a small part of the transportation mission years ago, its responsibility has increased a lot today. So much so that more than two billion passengers and millions of tons of freight are transported every year. In 2006, it is observed that the total world income traffic in scheduled airlines exceeded 510 billion tons of income (1), which includes almost four trillion revenue passenger kilometers. (2) In addition, the total revenues of the scheduled airlines of the parties to the international civil aviation Convention (Chicago Convention) of December 1944 in the same year exceeded US \$ 2007 billion, more than 1990 percent above 450 levels. Due to the increasing growth and characteristics of the aviation industry, its contribution to climate change has become an important issue. About half of the domestic aviation industry increased significantly between the '84 and 90's [16].

In 2010, 211 million passengers passed through UK airports; their number has increased 100 times since 1950 and is estimated to reach 2030 million by 480 despite recent declines. In 2009, air transportation used 12.7 million tons of fuel. This was $17.5 \%$ of total final petroleum products consumption and $23.2 \%$ of those consumed by the entire transport industry [17]

The increase in the number of passengers and the rapid development of the aviation sector have made the literature studies important for aviation fuels. It will be useful to understand the types of fuel that the fastgrowing sector will use and use from past to present. Jet fuel is a general name given to aviation fuels used for gas turbine engines. Traditionally, jet fuel, kerosene, is obtained by the distillation fraction of 150 to 2758 degrees of crude oil, a complex mixture of many different chemical compounds. The main components are linear and branched alkanes and cycloalkanes with a typical carbon chain length distribution of C6-C16. Chemical properties for various jet fuels are given in Table 1 [18]. In Table 1, Jet A-1, Bio-SPK, FT-SPK were compared.

Table given, Jet A-1 Commercial jet fuel [20], Bio-SPK jatropha fuel and FT-SPK fuel [19]. (\% by weight) chemical compound; Bio-SPK [20] S.P.A. refers to "small percentage". Air transport, which appeared in the first quarter of the 20th century, showed a rapid development after the second world war. The fact that aircraft manufacturers produced wide-body aircraft models with new technology engines accelerated this development. 
Table 1. Chemical compound of jet fuel

\begin{tabular}{lccc}
\hline Compound (wt\%) & Jet A-1 & Bio-SPK & FT-SPK \\
\hline Polycyclic alkanes & 7.3 & S.P. & 29.1 \\
n-Alkanes & 19.6 & $\sim 10$ & 2.7 \\
Alkyl benzenes & 14.1 & 0 & 11.2 \\
Monocyclic alkanes & 20.3 & S.P. & 13.8 \\
Iso-alkanes & 29.9 & $\sim 90$ & 42.8 \\
Other hydrocarbons & 8.7 & 0 & 0.4 \\
\hline
\end{tabular}

Today, the development continues with engines that offer more economical fuel consumption with new models with narrow and wide bodies.

The need for jet fuels has become undeniable day by day. It is thought that the current need of 320 million tons per year will be 430 million tons by 2040 [21]. Jet fuel accounts for approximately $20 \%$ of the production of US oil facilities over the past three decades [22]. Jet fuels constitute a large area in the consumption of fossil fuels with a very high market value. Jet fuels continue to rise steadily. It is known that the United States consumes approximately 2000 thousand barrels of jet fuel per day [23].

Over the past two decades, aviation energy efficiency has been improved more domestically than in the international arena. Energy efficiency measurements enter a more efficient fleet of aircraft, and seat miles per gallon and full seats of the aircraft are both dependent on efficiency and sharing and are measured in British thermal units per passenger, with energy density per passenger, aircraft miles per gallon that improves measurably [22].

The fact that oil prices tend to increase over the years in air transportation increases fuel costs. For this reason, fuel producers and airline companies have sought many alternative fuels. Since air vehicles have an important place in the transportation sector, biomass has the greatest potential in the search for renewable energy sources [24]. Biological materials containing vegetable and animal based and containing carbon dioxide compounds are energy sources [25]. Fuels produced from these are called biofuels [26-28]. Biofuels are an important sustainable energy resource for new markets, which greatly reduces greenhouse gas impact, improves weather conditions, reduces dependence on oil produced from fossil fuels [26]. In this study, it is aimed to reveal all aspects of modern fuel types in the aviation industry, their effects on the environment and the use of fuel by making statistical data.

\section{Results and Discussion}

With an annual growth rate of $5 \%$, an extra $3 \%$ fuel consumption occurs in the aviation industry every year. With this growth, the consumption of fossil fuels has increased and has led to the need for renewable fuels and energy sources [18-29]. The most important factors related to alternative fuels are the dependence on the countries that supply oil, having environmentally friendly technology, being renewable, carbon dioxide recycling and sustainable [30].

\subsection{Fossil Based Aviation Fuels}

Jet fuel is an aviation fuel designed for use in gas turbine engines in aircraft. Its color can range from clear to light yellow. The most commonly used commercial aviation fuels are Jet $\mathrm{A}$ and Jet $\mathrm{A}-1$. These fuels are produced with standardized international features. Jet fuel is a mixture of a large number of different hydrocarbons. Size ranges, such as molecular weight and carbon number, are limited for product requirements. Examples of these product requirements are freezing point or smoke point. Hydrocarbon mixtures from different molecular classes, including $\mathrm{n}$ paraffin, iso-paraffin, cycloalkanes and aromatics, are the most widely used aviation fuels [30-31]. Due to its physical properties, ease of use and stability in the USA, jet fuels commonly used for aircraft and missiles are JP-8 and JP10 [32]. Current additive, the United States has developed many jet fuels. These fuels can be listed as JP-4 (NATO code, F-40), JP-5 (NATO code, F44), JP-7, JP-8 (F-34), JP-TS, JP-8, Jet A [33].

\subsubsection{Jet A1-Jet A}

Jet $A 1$ is the name given to the type of fuel whose main ingredient is kerosene and is used today in passenger and cargo aircraft with jet engines worldwide. Kerosene, the main substance of Jet $A 1$, is actually a flammable hydrocarbon liquid. It is derived from the Greek word "keros". Kerosene is a gas oil called "paraffin oil". It is obtained by very fine distillation of Crude oil between $150^{\circ} \mathrm{C}$ and $270{ }^{\circ} \mathrm{C}$. It is generally used in the field of heating and lighting. Gas burns relatively harder but gives more heat than gasoline. The degree of flash point is $38^{\circ} \mathrm{C}$. The selfignition degree is $210^{\circ} \mathrm{C}$. The self-ignition degree is $210^{\circ} \mathrm{C}$. In such cases, foam, chemical and water fog 
are used to extinguish the fire. The freezing point of the chrome is around $-47^{\circ} \mathrm{C}$. Due to these features; In other words, it is preferred as "aircraft fuel" because it does not freeze easily at low temperatures at high altitude and reduces the risk of fire in the event of an accident to the minimum possible. The main difference between Jet $A 1$ and Jet $A$ is their freezing degrees. While both types of fuel ignite at $38^{\circ} \mathrm{C}$, Jet $\mathrm{A}$ freezes at $-40^{\circ} \mathrm{C}$ and Jet $\mathrm{A} 1$ freezes at $-47^{\circ} \mathrm{C}$ [28]

\subsubsection{Jet $B$}

Jet B contains light compounds as it consists of naphtha-kerosene mixture. This feature causes high flammability, making it difficult to use. Jet $B$ is a civilian version of JP 4 Jet $B$ type fuel oil, the freezing rate of which drops down to $-60^{\circ} \mathrm{C}$, is rarely used in the commercial airline industry, but it is preferred in countries where Canada, Alaska and Russia prevail due to its very low freezing degree [28]

\subsubsection{Avgas}

Avgas (aviation gas indoline) piston-engine is used in aircraft. Avgas is used in Wankel engines and piston engines. Performance and safety measurements have been made according to many environments and its octane value is quite high. The use of avgas in the USA in 2008 is $700000 \mathrm{~m} 3$ per year, and the engine accounts for approximately $0.14 \%$ of gasoline consumption [34].

\subsubsection{Jet P4}

JP-4 is a jet fuel defined by the American government in 1951. This fuel is produced by adding half kerosene and gasoline. It has a lower flash point than JP-1, but the reason for its preference is due to its widespread availability. It was the primary jet fuel of the United States Air Force from 1951 to 1995. The NATO code is F-40. It is a flammable fuel with a light yellow transparent color, kerosene-like odor, and has properties such as easy evaporation and floating on water. It also consists of a mixture of aliphatic and aromatic hydrocarbons and has a low flash point of -18 . $\mathrm{JP}-4$ freezes at $-60^{\circ} \mathrm{C}$ and the highest burning temperature is $3,688^{\circ} \mathrm{C}$. A similar mixture called Jet-B is used in commercial aviation. In addition, JP-4 contains corrosion inhibitors and icing inhibitors [35].

\subsubsection{Jet P5}

JP-5 or JP5 ("Jet Propellant" - Jet fuel) is a jet fuel with 1 liter of $0.81 \mathrm{~kg}$ and a high flash point (at least $60^{\circ} \mathrm{C}$ ). This fuel was developed in 1952 for the use of aircraft-on-aircraft carriers with a high fire risk.
JP-5 is still the primary fuel for most navies. The NATO code of this fuel is F-44. It is also referred to as AVCAT (Aviation Carrier Turbine Fuel). JP-4 and JP-5 fuels contain MIL-DTL-5624 U features. Fuel in these properties is designed for use in aircraft turbine engines. These additives add military-specific additives that are required to be used in military weapons systems. This requirement is specific to military aircraft, engine designs and missions. JP-5 is a complex mixture containing hydrocarbons, naphtha and aromatic hydrocarbon [35-37].

\subsubsection{Jet $P 7$}

JP-7 is a jet fuel produced by the United States Air Force for supersonic aircraft. It has a high flash point and thermal stability. Containing major hydrocarbons such as JP-7 alkanes, cycloalkanes, alkylbenzenes, indan / tetralin, added to increase lubrication properties, oxidizers added for better combustion and Cesium, also known as A-50, which helps prevent detection of the exhaust distributor by radars. It is a fuel mixture created by adding a compound. JP-7 distillation product is an unusual type of fuel because it is not a fuel. This fuel is a highly volatile fuel mixture containing components such as benzene, toluene in very low concentrations $(<3 \%)$ and almost without sulfur, oxygen or nitrogen impurities. This fuel has low vapor pressure and high thermal oxidation stability.

\subsubsection{Jet P8}

In the 1980s, it was decided by NATO countries to use a single fuel (JP-8) for all military aircraft and vehicles in the European war zone. This idea became known as the single fuel concept (SFC) [39]. Such a decision was made not only because of the great logistics awards at the time of war, but also because of the more pragmatic fact of NATO to simplify and better use it in times of peace. The only fuel chosen was the F-35 (Jet A-1) military Jet kerosene based on civil jet fuel F-34 (JP-8) [40-45]. Compared to the $-18^{\circ} \mathrm{C}$ flash point of JP-4, the higher and safer is $38^{\circ} \mathrm{C}$. The flash point of JP-5 is even higher $\left(>60^{\circ} \mathrm{C}\right)$ [35].

\subsection{Environmental Effects of Fossil Based Fuels}

CO2 emissions increase by about five percent each year compared to the previous year. In 2010 and $22 \%$ of this originates from the transportation sector. Within this sector, road and airline vehicles should be fed with an environmentally sustainable energy source. In 2009, the world's first industry-specific climate 
change goals were collectively adopted by the aviation industry. These targets were determined as carbon neutral growth from 2020 [36].

The predictive model for international aviation is a model developed by the Dutch Bureau of Economic Policy Analysis (CPB, 1999) that is used to calculate future jet fuel emissions for the world's economic development, with scenarios starting from the $90 \mathrm{~s}$ to 2050.CO2 emissions from jet fuel are thought to increase between 200 and 500\%, respectively, between 1995 and 2050. As a source of CO2 emissions, all aviation could exceed $15 \%$ of all CO2 emissions by 2050 [16].

Research shows that international aviation carbon dioxide emissions will increase by more than 110 percent over 20-year periods and may be offset at levels consistent with climate targets. Commercial aviation accounts for about $2.6 \%$ of annual global $\mathrm{CO} 2$ emissions [37-38].

CO2 emissions associated with civil aviation will increase by $100-500 \%$ from 1995 to 2050, according to Britain's Ministry of Commerce and Industry (DTI). The Environmental Defense Fund (EDF) made $500-1100 \%$ estimates (during the 1990-2050 period) with a $300 \%$ increase base scenario. In addition, reference scenarios say that future emissions may increase in the period of 1995-2050. Emissions will be limited to current levels only in the case of a low scenario and a very high tax (\$1500 per ton!). Currently, fuel prices account for about $8-13 \%$ of airline costs.; fuel costs in the airline cost will increase to $90 \%$ in the future. This seems economically above imagination. Carbon emissions have grown by $2.0 \%$, the fastest growth over the past seven years [39].

The compilation and research of the studies were carried out by international organizations and organizations specialized in their field. The scenario with a medial yearly growth of approximately $1 \%$ for the 2013 period starts from a very low 7-year forecast. $0.9 \%$ for 2016 and $2017-2020$ period. The accumulation of these factors explained in the studies also created a very pessimistic picture and led to a decrease in domestic and international flight demand. In the crisis scenario, this negative forecast will recover somewhat from 2020 to 2030 at a slow pace and a slow growth rate of $1.1 \%$ by the end of 2030 [40].

Other scenario assumes a fast and solid recovery of the EU economy with an average annual growth rate of $3.3 \%$, and returns to pre-crisis growth rates in the middle of the current decade, starting from the high growth scenario of its 2013-2016 and 20172020. This scenario is quite strong economic growth international markets offer the most demanding traffic situation for Europe, backed by a high range of high consumer spending in the US and slight descent of emerging Chinese economy, open skies agreement, stable fuel prices. Exhaustive, the expected annual average growth is at the highest level of all scenarios, ranging from $3.2 \%$ to $3.5 \%$ for the period $3.3-2013$ 2030. In the 2010 EUROCONTROL report Forecasts made in the 20-year period know the number of lost flights 2 to 2025 million inadequate airport capacity in the strongest growth scenario [40].

\subsection{Alternative Fuel Potential for the Aviation Sector}

First times of the jet aircraft, speed, quality and luxury were an incentive for intercontinental travel. Thenceforth, he has been an enormous driver, the center of efficiency, air travel and modern life. Sustainable aviation fuel is essential to power the world's aircraft fleet and provide a cleaner fuel source to help billions of people traveling by air every year reduce the impact of their travel on our planet. Approximately $2 \%$ of global human-sourced carbon emissions are due to the aviation industry. When the traffic situation was considered in 2016, it was observed that there were 35.8 million scheduled commercial flights carrying about four billion passengers. According to estimates, the annual passenger numbers of aviation are expected to increase from 6.9 to 2035 billion. This increase means that effective action is required to reduce carbon emissions to supply the sustainable development of the industry [41].

After the first biofuel test took place in a commercial flight in 2008, many studies were conducted. After the global fuel standards agency ASTM allowed the use of these fuels in 2011, more than 225,000 flights were carried out with a sustainable-fossil fuel blend [42]. Recently, demands for better energy use due to the rise in oil prices and Global Climate Change and other environmental concerns have come together to strengthen the need to increase Travel efficiency in terms of both reducing fuel use and environmental impact [43-44].

With its growing demand for air transport and concerns about its environmental impacts, however, non-derived alternative jet fuels - from conventional sources such as coal, natural gas, and biomass and environmentally sustainable, aviation has become an important strategy to achieve high performance [45]. Various advanced aviation fuels have been developed in recent years [46-47]. Some of these were used especially for military aircraft and propulsion. 


\subsubsection{Sustainability in Aviation}

All over the world, biofuels are the most demanded alternative fuels as they are very important in sustainable development. Biofuels provide a better mix of energy and a transition from a fossil dependent economy to a bio containing economy. In recent years, interest in biofuels has been increasing in the aviation sector and production part. Major organizations in the aviation industry, the International Air Transport Association (IATA) and the international civil aviation Organization (ICAO), have committed to significantly reducing emissions and neutralizing the increase in carbon emissions [48-49]. Previous studies in the literature examined the greenhouse gas (GHG) emissions and effects of aviation biofuels produced with different technological tools and methods [50-51].

All these studies have shown that fossil fuel reserves are decreasing and carbon dioxide levels in the atmosphere are increasing rapidly. This has raised concerns and accelerated progress in alternative jet fuel research [52-53]. All these orientations may not work in the short run. Synthesis pathways have been developed, including Sugar and Salvi [54-57], bioFischer Tropsch syngas, catalytic conversion Animal and vegetable oils hydro processing to produce bio-jet fuels from different biomass feedstocks. Vegetable oilbased fuels such as camellia, jatropha and algae oil come to the fore among the fuels that can be alternatives to petroleum-type fuels used in aviation.

In addition to these, hydro processing of natural waste triglycerides and fatty acids are the most recommended forms in the literature for the production of alternative jet fuels [58-59]. Long chain hydrocarbons are produced by hydro deoxygenation, carbonization and decarboxylation. Generally, a hydrocracking step is also required to obtain the desired $\mathrm{C} 8-\mathrm{C} 16$ hydrocarbons [60-61]. This technology has reached a certain level. Airline companies carried out test flights with biofuels from various vegetable oils and animal oils [63]. There are two promising renewable alternatives that can replace oil with the technology currently used for the production of renewable jet fuel. These; Bio (Bio-SPK) Synthetic Paraffinic Kerosene Obtained (FTSPK), renewable oils and biomass, and Fischer Tropsch Synthetic Paraffinic Kerosene produced respectively [63]. Bio-SPKs are produced from recycled resources. These sources are plants, algae, triacylglycerols and fatty acids, which are trans esterified. Hydrocracking and hydrotreating are then produced, producing alkanes of desired length, saturation, and branching. FT - SPK was obtained by pyrolysis of biomass to synthetic gas (syngas), Fischer - Tropsch synthesis of longer chain alkanes, hydrotreating and separation. Even though the chemical composition of SPks and petroleumcontaining fuels is different (Table 2), they are still very similar in terms of their basic properties (Table 1) and their performance in modern jet aircraft. The synthesis of $\mathrm{CMB}$ is well established and the products have been successfully evaluated by major commercial airlines as a 1:1 mixture with petroleum-based kerosene [23]. As the aviation industry's demands for jet kerosene rose to more than $5 \%$ of all refined products from the raw material, the refinery needed to optimize its jet kerosene yield with improved production techniques. The use of additives is often necessary, and sometimes even necessary, due to the number and severity of the processes used. These additives can prevent the formation of harmful chemical species or increase the characteristics of the fuel to prevent further engine wear. In addition, additives were subjected to an extensive and expensive treatment of all fuel properties and their effects on acceptability for use were studied. This process can take many years before an additive is approved [64].

Apart from all these uses and productions, alternative fuels are generally two types, and can be classified as renewable and fossil renewable. Alternatives to fossil-based aviation fuels that have been used since the past, sustainable aviation fuels and some flat vegetable oils can also be used [65]. Fuels such as sustainable aviation fuel have the advantage that the aircraft itself needs little or little changes, provided that its fuel characteristics meet the lubrication and density properties of existing aircraft fuel systems as well as the sufficiently swollen elastomer seals [66]. Sustainable aviation fuel and alternative fuel mixtures of fossil and sustainably sourced provide lower particle emission and greenhouse gas emissions [67]. However, they are not used extensively. Because they are still facing political, technological and economic obstacles such as being more expensive than traditionally produced aviation fuels [68].

The reasons for using unconventional or alternative fuels can be mentioned as contributing to meeting increasing energy demands, reducing crude oil dependency, preventing the depletion of crude oil reserves, limiting periodic leaps in crude oil prices, and reducing harmful effects on the environment and human health [69]. Replacing fossil energy carriers that pollute the environment and implementing renewable energy sources instead, quality control, low investment costs, safe political independence of foreign fuel sources, using uncultivated areas will contribute to the protection of soil and water.

However, alternative fuels for internal combustion engines must have overlapping requirements with gasoline and diesel gas oils [69]. 
These requirements can be determined by the ease of use and production of environmental hazards for engines that do not contain compounds that have been proven or have low amounts, high energy content, required evaporation rate, corrosivity, thermal stability, etc. Problems for alternative fuels are whether they are applicable to existing engines, call for very little replacement of existing engines, comply with environmental concerns and human health concerns, and cannot be operated at the same minimum cost as traditional fuels and are not of high quality.

\subsubsection{Sustainable Aviation Fuel Pathways}

Today there are five approved SAF production methods and each represents different processes and different raw materials [41]. The most commonly used process processes are given in the Table 2.

Although renewable aviation fuels can be produced from a wide variety of materials, they are generally produced with triglycerides, lignocellulos ides and syngas. In addition, biofuels can be obtained from plants, animal fats and biomass [70]. A biofuel produced from biomass, such as plants or organic waste, has the potential to reduce $\mathrm{CO} 2$ emissions while helping to reduce dependence on oil and greenhouse gas production, because plants use $\mathrm{CO} 2$ as they grow [71-73].

Apart from all these, bacteria are also used in biofuel production. It has the capacity to produce numerous potential precursors and ready-made fuel molecules such as bacteria, yeast and algae ethanol, alkanes and $\mathrm{H} 2$. This feature is part of its natural metabolism. The range of product chemistry can be further extended by changing known methods or creating synthetic pathways through metabolic engineering [73].

HEFA is another production method of sustainable fuels. This technology is based on the hydro processing of vegetable oils and animal fats. Its chief advantage is integrating this process into an oil refinery and eliminating the need to develop a dedicated production facility [74]. However, pure vegetable oil cannot be used directly on gas turbine aircraft. To be able to use them, they need to be modified to bring their combustion-related properties closer to diesel ones.

Alternatively, hydrogenation of vegetable oils and animal fats can produce liquid alkanes suitable for use in gasoline, diesel or jet fuel applications [75-76]. For example, triglyceride containing an oleic acid is performed in three steps: hydrogenation, reduction and deoxygenation, decarboxylation and decarboxylation.

It is known as FT synthesis for the production of sustainable fuels in another form. FT synthesis is a catalytic chemical process in which a gas obtained from the gasification of a raw material is used to process it to produce a synthetic fuel. In FT synthesis, conditioned synthesis gas is converted into liquid and solid hydrocarbons. The resulting products can be decomposed into NAFTA, diesel or jet fuel and candles, and combustible gases such as propane and butane. FT production has already been approved to produce jet fuels from coal, biomass and natural gas raw materials (when blended with traditional jet fuel $50 \%$ ) and current developments, shows that FT fuels from biomass are technically possible

In addition, sustainable fuel DME, suitable for gas turbine aircraft; Dimethyl ether ( $\mathrm{CH} 3 \mathrm{OCH} 3)$. DME; Also known as wood ether. It can be made from natural gas, coal or biomass. Dimethyl ether (DME) is the simplest ether compound. It is a new alternative fuel, non-toxic, environmentally friendly, with a high cetane number of about 55-60, and its properties are quite different from that of diesel fuel. The fuel supply system, injection system and combustion system of the gas turbine will be redesigned or modified, since the heat value of the DME is significantly lower than that of conventional diesel fuel [75].

\subsubsection{Sustainable Avıatıon Fuel-Providing Environmental Benefits}

Gas turbine engines in aircraft spends a lot fossil-based fuel. Today, fuel expenses accounts for approximately half of airline companies' expenses. Simultaneously fossil based fuels cause air pollution.

Table 2. Pathways processes

\begin{tabular}{ccc}
\hline ASTM D7566 & Feedstock/Blending & Date of approval \\
\hline FT-SPK & Biomass- $\% 50$ & 2009 \\
HEFA-SPK & Oil-bearing biomass-\%50 & 2011 \\
HFS-SIP & Microbial conversion of sugars to hydrocarbon-\%10 & 2014 \\
FT-SPK/A & Renewable biomass $-\% 50$ & 2015 \\
ATJ-SPK & Agricultural wastes products - $\% 30$ & 2016 \\
HEFA + & Oil-bearing biomass- $\% 50$ & 2018 \\
\hline
\end{tabular}


Because of these reasons, energy obtaining types have undergone changes humanity research for sustainable and friendly to nature sources. Biomass based alternative fuels will replace fossil-based fuels in the coming years [77].

Sustainable aviation fuels have great significance in terms of competition with fossil-based fuels and cleaner sky. There are a few challenges to overcome for sustainable aviation fuels; acquisition challenges, distribution, environmental challenges, raw material supply and sustainability, and the most importantly, protect nature. As a result of international and national researches, reducing $\mathrm{CO} 2$ emissions have great importance for future generations. This importance has been recognized in air and land transportation for a long time and legal impositions have been implemented. Under this scope, International Air Transport Association (IATA) has installed a number of visions to airline companies to reduce CO2 emissions from air transport IATA2015. Firstly, modern and efficient aircrafts will be included in the sector and fuel efficiency will increase \%1.5 by 2020 secondly emissions that the aviation industries cannot reduce will be balanced by economic measures. Net carbon emissions stabilize at 2020 values. Finally, with the use of technology and high sustainable fuel combination emission values in 2050 will be reduced to half of 2005 [77].

In 2005, $2.5 \%$ of man-made CO2 originated from the aviation industry and this value is expected to be between $4 \%$ and $4.7 \%$ in 2050 [78-79]. Aircraft engine-induced aviation sector emission values affect the atmosphere simultaneously radiation stability of the climate system. The first way to reduce greenhouse gas emissions in aviation is biofuels [60]. Increasing demand for biofuels affects biodiversity soil fertility and has also contributed to the increase in atmospheric co2 density [80] on the long view the intensive use of agricultural crops to obtain biofuels will negatively affect soil quality and water availability. Worse, the use of these lands for different purposes will result in food shortages. Simultaneously, efficiency enhancing products such as pyrethrum powder and fertilizer will increase which will cause soil and water pollution [80] change of fuel systems and types of production should not adversely affect human life [81]. Sustainable aviation fuels are basically similar and their fuel features must meet standards based on flight and climate conditions [82].

Sustainable aviation fuels have several advantages, especially potential to reduce greenhouse gases, have been accepted by the International Civil Aviation Organization and member states, and an action plan has been developed. According to the international civil aviation organization (ICAO) 2016 assessment, if fossil-based fuels are completely sustainable $63 \%$ of $\mathrm{CO} 2$ emissions may be replaced by 2050 [83].

\subsubsection{Certification and Demonstration}

The history of aviation is written with a pen, the ink of which is blood, so the first priority of the aviation industry has always been security. For this reason, the requirements and the testing process of new fuel mixes that are likely to be used in aviation are extremely rigorous. Laboratory tests ground equipment tests and flight operations determine the availability of sustainable aviation fuels. Then sustainable aviation fuels can be approved for commercial use. Consequently, it is necessary to confirm the availability and reliability of sustainable aviation fuels. The aviation industry works closely with international fuel specification companies such as ASTM international [42].

Table 3. jet fuel specifications

\begin{tabular}{|c|c|c|}
\hline Criteria & Explanation & Jet $A-1$ specification \\
\hline Flash point & $\begin{array}{l}\text { The temperature at which the fuel } \\
\text { ignites in the engine to cause } \\
\text { combustion to occur }\left({ }^{\circ} \mathrm{C}\right)\end{array}$ & $38^{\circ}$ minimum \\
\hline Freezing point & $\begin{array}{l}\text { The temperature at which the fuel } \\
\text { would freeze }\left({ }^{\circ} \mathrm{C}\right)\end{array}$ & $-47^{\circ}$ \\
\hline Combustion hea & $\begin{array}{l}\text { The amount of energy that is } \\
\text { released during combustion, per } \\
\text { kilo of fuel }(\mathrm{MJ} / \mathrm{kg})\end{array}$ & $42.8 \mathrm{MJ} / \mathrm{kg}$ minimum \\
\hline Viscosity & $\begin{array}{l}\text { The thickness of the fluid or ability } \\
\text { to flow }(\mathrm{mm} 2 / \mathrm{s}\end{array}$ & $8.000 \max$ \\
\hline Sulphur content & $\begin{array}{l}\text { The amount of sulphur in the fuel } \\
\text { (parts per million) }\end{array}$ & 0.30 \\
\hline Density & $\begin{array}{l}\text { How heavy the fuel is per litre } \\
(\mathrm{kg} / \mathrm{m} 3)\end{array}$ & $775-840$ \\
\hline
\end{tabular}


ASTM has created the standard D7566 for mixtures of fossil-based and sustainable fuels. This standard complements the existing ASTM standard D1655 for fossil-based jet fuel. Technically, sustainable aviation turbine fuel is produced and certified according to the D7566 standard and shall be regarded as Specification D1655 turbine fuel. easily explained, a non-fossil based sustainable fuel meets the requirements of the D7566 standard is, on technical fitfor-use grounds, $100 \%$ equivalent to fossil-based aviation fuel kerosene. this is an important distinction from the use of biodiesel and ethanol in road transportation sector [36].

In 2009, it was approved to use the FischerTroph process to obtain ASTM International sustainable fuel. In 2011, fuel production from hydro worked esters and fatty acids was added to the standard as D7566-11. The standard states that these fuels, which can be biomass based, can be used in commercial aviation, 50/50 blend with fossil-based jet fuel approved by ASTM also HEFA process was approved by ASTM in 2014 [22] .in the coming years Hydro processed Fermented Sugars to Synthesized Iso-Paraffin (HFS-SIP) process and Alcohol to Jet Synthesized Paraffinic Kerosene (ATJ-SPK) process approved by ASTM [84].

\section{Conclusion}

In this study, fuels in the aviation industry are explained in detail from past to present. Advantages and disadvantages of all fuel types have been evaluated. In the light of all the studies carried out, it has been concluded that it is necessary to switch to sustainable resources based on statistical information. Considering both economic dependency and its impact on the environment, it is predicted that the cost factor can be discarded. This is inevitable considering that the emission values increase rapidly every year, global warming cannot be prevented and the demand for the aviation sector increases. When looking at the production methods, it is noteworthy that it is necessary to start the work without losing time by cooperating with airline companies. Many airline companies contribute to this issue, but they are insufficient. It is concluded that the projects carried out with companies by the authorities related to sustainable alternative aviation fuels for a more livable and cleaner environment as a whole are initiated and should be implemented.

\section{References}

[1] E. Koc, M.C. Şenel, Dünyada ve Türkiye'de enerji durumu-genel değerlendirme, Mühendis ve Makina, 54 (2013) 32-44.
[2] H.Yağlı, Y. Koç, A. Koç, A. Görgülü, A. Tandiroğlu, Parametric optimization and exergetic analysis comparison of subcritical and supercritical organic Rankine cycle (ORC) for biogas fuelled combined heat and power (CHP) engine exhaust gas waste heat, Energy, 111 (2016) 923-932. [DOI]

[3] H.Yagli, A. Koc, C. Karakus, Y. Koc, Comparison of toluene and cyclohexane as a working fluid of an organic Rankine cycle used for reheat furnace waste heat recovery, International Journal of Exergy, 19 (2016) 420438. [DOI]

[4] A. Koç, H.Yağlı, Y. Koç, İ. Uğurlu, dünyada ve türkiye'de enerji görünümünün genel değerlendirilmesi, Mühendis ve Makina, 59 (2018) 86-114.

[5] International Energy Agency, (2017) Key World Energy Statistics. https://doi.org/10.1787/key energ stat-2017-en

[6] International Energy Association, (2017) World energy balances: overview, IEA

[7] M.M. Odası, (2018) Türkiye" nin Enerji Görünümü 2018. Oda Raporu, Yayın No MMO/691, Ankara. https://www.mmo.org.tr/sites/default/files/Enerii Gorunumu2018 1.pdf

[8] T. C. Enerji, (2016) Mavi Kitap-Enerji ve Tabii Kaynaklar Bakanlığı ile Bağlı, İlgili ve İlişkili Kuruluşlarının Amaç ve Faaliyetleri. http://www.sp.gov.tr/upload/xSPRapor/files/sEJ gO+Enerii ve Tabii Kaynaklar Bakanligi 201 6 Yili Faaliyet Raporu.pdf

[9] B.E. Outlook, (2019) 2019 edition, London, United Kingdom.

[10] G. Kalghatgi, Development of fuel/engine systems the way forward to sustainable transport, Engineering, 5 (2019) 510-518. [DOl]

[11] M.N. Smith, (2016) The number of cars worldwide is set to double by 2040, In World Economic Forum, Geneva.

[12] W.M. Colton, (2011) The Outlook for Energy: A View to 2040, Exxon Mobil Corporation.

[13] P. Gadonneix, A. Sambo, L. Tie'nan, A.R. Choudhury, J. Teyssen, J.A.V. Lleras, Abbas Ali Naqi, K. Meyers, H.C.Shin, M.J. Nadeau, G. Ward, M. Morris, B. Statham, C. Frei, (2011) Global transport scenarios 2050, World Energy Council, London. 
[14] M. Nilsson, (2016) Organization of the Petroleum Exporting Countries (OPEC), In International Organizations and The Rise of ISIL, Routledge,

[15] W.M. Colton, (2011) The Outlook for Energy: A View to 2040. Exxon Mobil Corporation.

[16] X. Olsthoorn, Carbon dioxide emissions from international aviation: 1950-2050, Journal of Air Transport Management, 7 (2001) 87-93. [DOI]

[17] T. Rutherford, (2011) Air transport statistics, House of Commons Library, United Kingdom.

[18] L.Q. Maurice, H. Lander, T. Edwards, W.E. Harrison lii, Advanced aviation fuels: a look ahead via a historical perspective, Fuel, 80 (2001) 747-756. [DOI]

[19] R.van der Westhuizen, M. Ajam, P. De Coning, J. Beens, A. de Villiers, P. Sandra, Comprehensive two-dimensional gas chromatography for the analysis of synthetic and crude-derived jet fuels, Journal of Chromatography A, 1218 (2011) 4478-4486. [DOI]

[20] J. D. Kinder, (2009) Evaluation of bio-derived synthetic paraffinic kerosenes, The Boeing Co., Sustainable Biofuels Research\& Technology Program.

[21] H.L. Wagner, (2009) The Organization of the Petroleum Exporting Countries, Infobase Publishing.

[22] C. Davidson, E. Newes, A. Schwab, L. Vimmerstedt, (2014) Overview of Aviation Fuel Markets for Biofuels Stakeholders, National Renewable Energy Lab, (NREL), Golden CO, United States.

[23] U.C. Bureau, (1999) Statistical abstracts of the United States, DC Comics, Washington. https://www.census.gov/library/publications/199 9/compendia/statab/119ed.html

[24] S.S. Sidibe, J. Blin, G. Vaitilingom, Y. Azoumah, Use of crude filtered vegetable oil as a fuel in diesel engines state of the art: Literature review, Renewable and Sustainable Energy Reviews, 14 (2010) 2748-2759. [DOI]

[25] A. Srivastava, R. Prasad, Triglycerides-based diesel fuels, Renewable and sustainable energy reviews, 4 (2000) 111-133. [DOI]

[26] P.S. Nigam, A. Singh, Production of liquid biofuels from renewable resources, Progress in energy and combustion science, 37 (2011) 5268. [DOI]

[27] I. Celikten, M. Guru, (2011) Petrodizel Ve Kanola Biyodizeli Performans Ve Emisyon Kriterlerinin Mangan Esasli Katki Maddeleriyle Geliştirilmesi, Journal of the Faculty of Engineering \& Architecture of Gazi University, 26 (2011) 643-648.

[28] C.M. Drapcho, N.P. Nhuan, T.H. Walker, (2008) Biofuel's engineering process technology, McGraw-Hill, New York

[29] E. Nygren, K. Aleklett, M. Hook, Aviation fuel and future oil production scenarios, Energy Policy, 37 (2009) 4003-4010. [DOI]

[30] C. Zhang, X. Hui, Y. Lin, C.J. Sung, Recent development in studies of alternative jet fuel combustion: Progress, challenges, and opportunities, Renewable and Sustainable Energy Reviews, 54 (2016) 120-138. [DOl]

[31] V.A. Alekseev, J.V. Soloviova-Sokolova, S.S. Matveev, I.V. Chechet, S.G. Matveev, A.A. Konnov, Laminar burning velocities of $n$ decane and binary kerosene surrogate mixture, Fuel, 187 (2017) 429-434. [DOl]

[32] T. Edwards, Liquid fuels and propellants for aerospace propulsion: 1903-2003, Journal of propulsion and power, 19 (2003)1089-1107. [DOI]

[33] P. Arkoudeas, S. Kalligeros, F. Zannikos, G. Anastopoulos, D. Karonis, D. Korres, E. Lois, Study of using JP-8 aviation fuel and biodiesel in $\mathrm{Cl}$ engines, Energy Conversion and Management, 44 (2003)1013-1025. [DOI]

[34] S. P. Srivastava, J. Hancsok, (2014) Fuels and fuel-additives, John Wiley \& Sons, USA

[35] J. P. Salanitro, (2001) Bioremediation of petroleum hydrocarbons in soil, Advances in Agronomy, 72 (2001) 53-105. [DOI]

[36] I. Perišin, (2016) Prepreke pri dizajniranju istraživačkog sustava zrakoplovnih nesreća, University of Zagreb Faculty of Transport and Traffic Sciences Division of Transport Department of Air Transport, Croatia.

[37] Z. Eller, Z. Varga, J. Hancsók, Advanced production process of jet fuel components from technical grade coconut oil with special hydrocracking, Fuel, 182 (2016) 713-720. [DOl]

[38] J. Hou, Z. Xia, S. Li, K. Zhou, N. Lu, Operation parameter optimization of a gas hydrate reservoir developed by cyclic hot water 
stimulation with a separated-zone horizontal well based on particle swarm algorithm, Energy, 96 (2016) 581-591. [DOI]

[39] C. G. Aviation, (2006) Aviation Fuels Technical Review, chevron, United States.

[40] M. Kousoulidou, L. Lonza, Biofuels in aviation: Fuel demand and $\mathrm{CO} 2$ emissions evolution in Europe toward 2030, Transportation Research Part D: Transport and Environment, 46 (2016) 166-181. [DOl]

[41] E. Salazar, S. Berman, (1981) Is There a Better Way to Power Airplanes? Energy Research Abstracts - 6. cilt - Sayfa 4185

[42] P.A. Conshohocken, (2004) ASTM International. Atanasova, B., Langlois, D., Nicklaus, S., Chabanet, C. et Etiévant, P. https://www.astm.org//MAGES03/b09 brochure .pdf

[43] International Air Transport Association, (2010) IATA 2010 report on alternative fuels. International Air Transport Association, International Air.

[44] J. Hileman, J.B. Katz, J.G. Mantilla, G. Fleming, (2008) Payload fuel energy efficiency as a metric for aviation environmental performance, $26^{\text {th }}$ International Congress of the Aeronautical Sciences.

[45] C. Zhang, X. Hui, Y. Lin, C. J. Sung, Recent development in studies of alternative jet fuel combustion: Progress, challenges, and opportunities, Renewable and Sustainable Energy Reviews, 54 (2016)120-138. [DOI]

[46] T. Edwards, Liquid fuels and propellants for aerospace propulsion: 1903-2003, Journal of propulsion and power, 19 (2003) 1089-1107. [DOI]

[47] X. Hui, K. Kumar, C. J. Sung, T. Edwards, D. Gardner, Experimental studies on the combustion characteristics of alternative jet fuels, Fuel, 98 (2012) 176-182. [DOI]

[48] B.Turner, (2010) International Air Transport Association (IATA), In The Statesman's Yearbook, Palgrave Macmillan, London. [DOI]

[49] R. Abeyratne, Outcome of the 39th Session of the International Civil Aviation Organization Assembly, Air and Space Law, 42 (2017) 1327.

[50] R.E. Bailis, J.E. Baka, Greenhouse gas emissions and land use change from Jatropha curcas-based jet fuel in Brazil, Environmental science \& technology, 44 (2010) 8684-8691. [DOI]

[51] E. Crossin, (2014) Mallee aviation biofuels life cycle assessment, Future Farm Industries CRC, Melbourne.

[52] B. Dudley, (2018) BP statistical review of world energy, BP Statistical Review, London, United Kingdom.

[53] N.Yilmaz, S.M. Davis, Polycyclic aromatic hydrocarbon (PAH) formation in a diesel engine fueled with diesel, biodiesel and biodiesel $/ n$ butanol blends, Fuel, 181 (2016) 729-740. [DOI]

[54] H.M. Mahmudul, F.Y. Hagos, R. Mamat, A.A. Adam, W.F.W. Ishak, R. Alenezi, Production, characterization and performance of biodiesel as an alternative fuel in diesel engines- $A$ review, Renewable and Sustainable Energy Reviews, 72 (2017) 497-509. [DOl]

[55] A. E. Council, (2016) Solar report, Australian Energy Council, Melbourne.

[56] OECD, IEA, (2012) Key world energy statistics 2012, Organisation for Economic Co-operation and Development and International Energy Agency.

[57] O. P. E. C. Secretariat, (2010) OPEC World Oil Outlook 2010, Organization of the Petroleum Exporting Countries.

[58] C. Gutiérrez-Antonio, F.I. Gómez-Castro, J.A. de Lira-Flores, S. Hernández, A review on the production processes of renewable jet fuel, Renewable and Sustainable Energy Reviews, 79 (2017) 709-729. [DOI]

[59] T. Li, J. Cheng, R. Huang, J. Zhou, K. Cen, Conversion of waste cooking oil to jet biofuel with nickel-based mesoporous zeolite $Y$ catalyst, Bioresource technology, 197 (2015) 289-294. [DOl]

[60] W.C. Wang, L. Tao, Bio-jet fuel conversion technologies, Renewable and Sustainable Energy Reviews, 53 (2016) 801-822. [DOl]

[61] L. Rye, S. Blakey, C.W. Wilson, Sustainability of supply or the planet: a review of potential drop-in alternative aviation fuels, Energy \& Environmental Science, 3 (2010) 17-27. [DOI]

[62] P. Gegg, L. Budd, S. Ison, The market development of aviation biofuel: Drivers and constraints, Journal of Air Transport Management, 39 (2014) 34-40. [DOl] 
[63] P. Steele, B. Pearce, A. Ríos, P. Nash, F. Massat, N. Young, T. Scott, (2011) Powering the future of flight, Proceedings of the World Biofuels $\quad$ Markets, 22-24. https://seors.unfccc.int/applications/seors/attac hments/get attachment?code=GRPR31ZA287 D3KAP5XOXQO2WP1JE9SQQ

[64] E. Aviation, (2008) World Jet Fuel Specifications with Avgas Supplement, ExxonMobil Aviation, Machelen

[65] M. Wang, M. Chen, Y. Fang, T. Tan, Highly efficient conversion of plant oil to bio-aviation fuel and valuable chemicals by combination of enzymatic transesterification, olefin crossmetathesis, and hydrotreating, Biotechnology for biofuels, 11(2018)1-9. [DOI]

[66] E. Corporan, T. Edwards, L. Shafer, M. J. DeWitt, C. Klingshirn, S. Zabarnick, J. Klein, Chemical, thermal stability, seal swell, and emissions studies of alternative jet fuels, Energy \& Fuels, 25 (2011) 955-966. [DOI]

[67] R.H. Moore, K.L. Thornhill, B.Weinzierl, D.Sauer, E.D'Ascoli, J. Kim, M. Lichtenstern, M. Scheibe, B. Beaton, A.J. Beyersdorf, J. Barrick, D. Bulzan, C.A. Corr, E. Crosbie, T. Jurkat, R. Martin, D.Riddick, M. Shook, G. Slover, C. Voigt, R. White, E. Winstead, R. Yasky, L.D. Ziemba, A. Brown, H. Schlager, B.E. Anderson, Biofuel blending reduces particle emissions from aircraft engines at cruise conditions, Nature, 543 (2017) 411-415. [DOI]

[68] "RREB report" (PDF). kic-innoenergy.com. Archived (PDF) from the original on 14 September 2016. Retrieved 7 May 2018. https://www.innoenergy.com/wpcontent/uploads/2016/03/RREB Biofuels in A viation Draft Final.pdf/

[69] J. Hancsók, (2004) Korszerủ motor-és sugárhajtómü üzemanyagok III, Alternatív motorhajtóanyagok, Veszprémi Egyetemi Kiado, Veszprém.

[70] C.C. Geddes, I.U. Nieves, L.O. Ingram, Advances in ethanol production, Current opinion in biotechnology, 22 (2011) 312-319. [DOI]

[71] S.N. Naik, V.V. Goud, P.K. Rout, A.K. Dalai, Production of first- and second-generation biofuels: a comprehensive review, Renewable and sustainable energy reviews, 14 (2010) 578-597. [DOI]
[72] M. de Souza-Santos, A feasibility study of an alternative power generation system based on biomass gasification/gas turbine concept, Fuel, 78 (1999) 529-538. [DOI]

[73] J.T. McEwen, S. Atsumi, Alternative biofuel production in non-natural hosts, Current opinion in biotechnology, 23 (2012) 744-750. [DOI]

[74] IATA-International Air Transport Association, (2017). IATA Sustainable Aviation Fuel Roadmap, 2015. https://www.iata.org/contentassets/d13875e9ed 784f75bac90f000760e998/safa-1st-edition2015.pdf

[75] Y. Zhang, D. Duan, H. Lei, E. Villota, R. Ruan, Jet fuel production from waste plastics via catalytic pyrolysis with activated carbons, Applied Energy, 251 (2019) 113337. [DOI]

[76] S. Khan, A.N.K. Lup, K.M. Qureshi, F. Abnisa, W.M.A.W. Daud, M.F.A. Patah, A review on deoxygenation of triglycerides for jet fuel range hydrocarbons, Journal of Analytical and Applied Pyrolysis, 140 (2019)1-24. [DOI]

[77] C.J. Mendez, R.N. Parthasarathy, S.R. Gollahalli, Performance and emission characteristics of butanol/Jet A blends in a gas turbine engine, Applied Energy, 118 (2014)135140. [DOI]

[78] F. Guo, J. Zhao, A. Lusi, X. Yang, Life cycle assessment of microalgae-based aviation fuel: Influence of lipid content with specific productivity and nitrogen nutrient effects, Bioresource technology, 221 (2016) 350-357. [DOI]

[79] M.O.P. Fortier, G.W. Roberts, S.M. StaggWilliams, B.S. Sturm, Life cycle assessment of bio-jet fuel from hydrothermal liquefaction of microalgae, Applied Energy, 122 (2014) 73-82. [DOI]

[80] B. Chèze, P. Gastineau, J. Chevallier, forecasting world and regional aviation jet fuel demands to the mid-term (2025), Energy Policy, 39 (2011) 5147-5158. [DOI]

[81] S. Liu, Q. Zhu, Q. Guan, L. He, W. Li, Bioaviation fuel production from hydroprocessing castor oil promoted by the nickel-based bifunctional catalysts, Bioresource Technology, 183 (2015) 93-100. [DOI]

[82] G. Marrs, R. Zamora-Cristales, J. Sessions, Forest biomass feedstock cost sensitivity to grinding parameters for bio-jet fuel production, 
Renewable Energy, 99 (2016) 1082-1091. [DOI]

[83] P. Steele, (2009) Why we need alternative fuels, In ICAO Workshop Aviation and Alternative Fuels.

[84] A. Zschocke, S. Scheuermann, J. Ortner, (2017) High biofuel blends in aviation (HBBA), Wiweb, 1-168.

\section{Funding}

No funding was received for conducting this study.

\section{Conflict of interest}

The authors have no conflicts of interest to declare that they are relevant to the content of this article.

Does this article screened for similarity?

Yes

\section{About the License}

(C) The author(s) 2021. The text of this article is open access and licensed under a Creative Commons Attribution 4.0 International License 